\title{
Bibliografia prac Profesor Barbary Bogołębskiej
}

Bibliografia obejmuje dorobek piśmienniczy Profesor Barbary Bogołębskiej z lat 1977-2018 w układzie chronologicznym. Część pierwsza zawiera publikacje książkowe, artykuły w czasopismach naukowych i rozdziały w monografiach, druga - prace redagowane, recenzje, hasła słownikowe, biogramy, głosy w dyskusji i inne.

W bibliografii wykorzystano informacje z baz danych Biblioteki Narodowej, Polskiej Bibliografii Naukowej, Polskiej Bibliografii Literackiej, Biblioteki Uniwersytetu Łódzkiego oraz materiały uzyskane bezpośrednio od Pani Profesor. Część opisów bibliograficznych sporządzona została $\mathrm{z}$ autopsji.

Oprac. Monika Worsowicz

\section{Część I - publikacje książkowe, artykuły w czasopismach naukowych, rozdziały w monografiach}

\section{7}

Z zagadnień teoretycznych stylistyki szkolnej dwudziestolecia międzywojennego, „Prace Polonistyczne", seria 33, s. 277-287.

\section{1}

Analiza, interpretacja i synteza dzieła literackiego, w: Przewodnik po tematach i literaturze z dydaktyki jezzyka polskiego, red. E. Cyniak, Wydawnictwo Uniwersytetu Łódzkiego, Łódź, s. 68-71.

Analiza utworów lirycznych, w: Przewodnik po tematach i literaturze $z$ dydaktyki języka polskiego, red. E. Cyniak, Wydawnictwo Uniwersytetu Łódzkiego, Łódź, s. 74-76.

Cele i zasady analizy dzieła literackiego, w: Przewodnik po tematach i literaturze $z$ dydaktyki języka polskiego, red. E. Cyniak, Wydawnictwo Uniwersytetu Łódzkiego, Łódź, s. 63-65.

Cele nauczania literatury, w: Przewodnik po tematach i literaturze z dydaktyki języka polskiego, red. E. Cyniak, Łódź, s. 38-40. 
Dydaktyka nauki o języku [współautor: J. Kwaśniakowa], w: Przewodnik po tematach i literaturze $z$ dydaktyki jezzka polskiego, red. E. Cyniak, Wydawnictwo Uniwersytetu Łódzkiego, Łódź, s. 145-166.

Kontynuacje normatywizmu w stylistyce szkolnej po $1900 \mathrm{r}$., „Prace Polonistyczne”, seria 37 , s. 303-326.

Nauczanie teorii literatury, w: Przewodnik po tematach i literaturze z dydaktyki jezzyka polskiego, red. E. Cyniak, Wydawnictwo Uniwersytetu Łódzkiego, Łódź, s. 56-58.

Wychowanie estetyczne, w: Przewodnik po tematach i literaturze z dydaktyki jezyka polskiego, red. E. Cyniak, Łódź, Wydawnictwo Uniwersytetu Łódzkiego, s. 45-48.

1987

O dwudziestowiecznych zwiazkach retoryki $z$ dydaktyka stylistyki, w: Dydaktyka literatury, t. 8, red. W. Pasterniak, Lubuskie Towarzystwo Naukowe, Wyższa Szkoła Pedagogiczna, Zielona Góra, s. 7-15.

Problemy badawcze $w$ stylistyce radzieckiej ostatnich dziesięciu lat, „Przegląd Rusycystyczny", z. 3-4, s. 92-103.

\section{9}

Edukacja stylistyczna a stan wspótczesnej metodologii, „Dydaktyka Literatury”, t. 10, s. 39-51.

\section{1}

Problematyka dydaktyki polonistycznej w dorobku twórczym profesor S. Skwarczyńskiej, „Dydaktyka Literatury”, t. 12, s. 55-64.

\section{3}

Proces wyodrębniania się teorii stylu na przełomie wieku XIX na XX, „Stylistyka”, t. 2, s. $163-172$.

\section{4}

Problemy szkolnego „badania” dzieła literackiego, w: $Z$ dydaktyki literatury i kultury w szkole, red. E. Cyniak, Wydawnictwo Uniwersytetu Łódzkiego, Łódź, s. 78-91.

\section{5}

Kategorie estetyczne $w$ dydaktyce polonistycznej, „Prace Naukowe Uniwersytetu Śląskiego. Z Teorii i Praktyki Dydaktycznej Języka Polskiego", nr 13(1437), s. 55-61. Koncepcja teoretycznoliteracka $w$ dydaktyce polonistycznej. Historia i wspólczesność, „Prace Naukowe Uniwersytetu Śląskiego. Z Teorii i Praktyki Dydaktycznej Języka Polskiego", nr 14(1499), s. 29-36. 


\section{6}

O nowe rozumienie funkcji retoryki w kształceniu polonistycznym, w: O narodowy i europejski wymiar edukacji literackiej i językowej, red. M. Sinica, Wydawnictwo Wyższej Szkoły Pedagogicznej, Zielona Góra, s. 168-176.

Problematyka synkretyzmu stylów w kształceniu polonistycznym, „Warsztaty Polonistyczne", nr 1, s. 56-60.

Retoryczna koncepcja stylu jako ozdoby tekstu, w: Styl a tekst, red. S. Gajda, M. Balowski, Uniwersytet Opolski, Opole, s. 77-82.

Tradycje retoryczne $w$ stylistyce polskiej. Narodziny dyscypliny, Wydawnictwo Uniwersytetu Łódzkiego, Łódź.

\section{8}

Mimetyzm czy kreacjonizm? (Obecność problematyki mimetyzmu w praktyce polonistycznej), „Warsztaty Polonistyczne”, nr 3, s. 39-43.

Romantyczny model retoryki i nauki o stylu. Przeglad problematyki, „Acta Universitatis Lodziensis. Folia Litteraria Polonica", t. 1, s. 139-152.

Spór o subiektywizm i obiektywizm w stylistyce, w: Sprawozdania z czynności i posiedzeń naukowych, t. 51, Łódzkie Towarzystwo Naukowe, Łódź, s. 175-181.

Świadomość genologiczna w polonistyce szkolnej międzywojnia, w: Teoria i praktyka kształcenia literackiego orazjęzykowego w latach 1918-1939, red. L. Jazownik, Wyższa Szkoła Pedagogiczna im. Tadeusza Kotarbińskiego, Zielona Góra, s. 55-61.

Wplyw teorii Wölfflinowskiej na badania stylistyczne, w: Sprawozdania z czynności i posiedzeń naukowych, t. 52, Łódzkie Towarzystwo Naukowe, Łódź, s. 137-143.

$Z$ rozważań nad językiem i stylem kaznodziejskim $w$ XIX-iXX-wiecznych retorykach, w: Funkcja stowa w ewangelizacji, red. M. Kamińska, E. Umińska-Tytoń, Archidiecezjalne Wydawnictwo Łódzkie, Łódź, s. 281-289.

Zygmunt Łempicki jako badacz stylu, „Stylistyka”, t. 7, s. 379-385.

\section{9}

Rozróżnienie stylistyki językowej i literackiej jako przedmiot polemiki naukowej, w: Sprawozdania z czynności i posiedzeń naukowych, t. 53, Łódzkie Towarzystwo Naukowe, Łódź, s. 197-204.

\section{0}

Między humorem, dowcipem i komizmem (śmiesznościa), czyli o zmaganiach terminologicznych autorów poetyk XIX i początku XX wieku, w: Świat humoru, red. S. Gajda, D. Brzozowska, Uniwersytet Opolski. Instytut Filologii Polskiej, Opole, s. 323-329.

Obrazowanie pojęć chrześcijańskich w księdze Cesarego Ripy „Ikonologia”, w: Inspiracje chrześcijańskie w kulturze Europy. Materiały z konferencji 11-14 maja 1999 r., cz. 2, red. E. Woźniak, Archidiecezjalne Wydawnictwo Łódzkie, Łódź, s. 93-101. 
Triada stylistyczna - historia i wspótczesność, w: Od średniowiecza ku wspótczesności. Prace ofiarowane Jerzemu Starnawskiemu w pięćdziesięciolecie doktoratu, red. J. Okoń, współpr. M. Kuran, Wydawnictwo Uniwersytetu Łódzkiego, Łódź, s. $154-163$.

\section{1}

Dyskurs krytycznoliteracki w polonistyce szkolnej, czyli o kształceniu kultury retorycznej, „Język Polski w Liceum”, nr 4, s. 11-18.

Edukacja polonistyczna (językowa, literacka i kulturowa) jako dialog między styla$m i$, w: Problemy poznawania dzieła literackiego w szkole. Tekst, kontekst, znak, znaczenie, red. T. Świętosławska, Wydawnictwo Uniwersytetu Łódzkiego, Łódź, s. $109-118$.

Motywy chrześcijańskie w „Encyklopedii staropolskiej” Zygmunta Glogera, w: Idee chrześcijańskie w życiu Europejczyka. Język, piśmiennictwo, sztuki plastyczne, obyczaje. Materialy z konferencji 15-17 maja 2000 r., cz. 2, red. A. Ceglińska, Z. Staszewska, Archidiecezjalne Wydawnictwo Łódzkie, Łódź, s. 155-164.

Perswazyjność dawnych i wspótczesnych podręczników sztuki pisania (stylistyk praktycznych), w: Język w komunikacji, t. 3, red. G. Habrajska, Wydawnictwo Wyższej Szkoły Humanistyczno-Ekonomicznej, Łódź, s. 141-147.

Słowo wstępne - słowo końcowe. Poetyka, retoryka, stylistyka, w: Konec a začátek vjazyce a literatuře. Sborník z mezinárodní konference, red. D. Moldanová, Univerzita Jana Evangelisty Purkyně, Ústí nad Labem, s. 124-129.

Studia o stylistyce i retoryce, Studio „Graf”, Zgierz.

Stylistyka retoryczna pozaliterackich form wypowiedzi. Wybrane aspekty problemu, w: Stylistyka a pragmatyka, red. B. Witosz, Wydawnictwo Uniwersytetu Śląskiego, Katowice, s. 139-151.

Wspótczesne poszukiwania "form bardziej pojemnych”, „Acta Universitatis Lodziensis. Folia Litteraria Polonica”, nr 4, s. 187-195.

Zabawy literackie Stanisława Barańczaka, „Stylistyka”, t. 10, s. 461-472.

\section{2}

Abecadła (alfabety) - popularna forma prozy wspomnieniowej (Czesława Miłosza, Ludwika Jerzego Kerna, Stefana Kisielewskiego), w: Literatura polska 19902000 , t. 2, red. T. Cieślak, K. Pietrych, Wydawnictwo „Zielona Sowa”, Kraków, s. $186-196$.

Dyskurs krytycznoliteracki w polonistyce szkolnej, czyli o kształceniu kultury retorycznej, „Język Polski w Liceum”, nr 4, s. 11-18.

Retoryka szkolna - między tradycją a wyzwaniami współczesności, w: W kręgu zagadnień dydaktyki języka i literatury polskiej. Ksiegga jubileuszowa dedykowana profesorowi Edwardowi Polańskiemu, red. H. Synowiec, Wydawnictwo Uniwersytetu Śląskiego, Katowice, s. 67-75. 
Ryszarda Skulskiego refleksje nad polonistyka szkolna, w: Polonistyka szkolna w latach 1918-1939. Koncepcje i polemiki, programy i ich realizacja, Oficyna Wydawnicza Uniwersytetu Zielonogórskiego, Zielona Góra, s. 79-86.

Sztuka dobrego pisania w ujęciu Antoine’a Albalata i autorów współczesnych, „Stylistyka", t. 11, s. 549-556.

Związki logiki z polonistyka szkolna. Przyczynek do interdyscyplinarności dydaktyki literatury i języka polskiego, w: Dziś i wczoraj edukacji polonistycznej. Ścieżki badawcze, red. A. Książek-Szczepanikowa, M. Wlazło, Wydawnictwo Naukowe Uniwersytetu Szczecińskiego, Szczecin, s. 32-42.

\section{3}

Autorytet jako argumentacja topiczna w podręcznikach twórczego pisarstwa, w: Autorytety i normy, red. D. Kowalska, Archidiecezjalne Wydawnictwo Łódzkie, Łódź, s. 39-45.

Funkcja delectare $w$ literaturze współczesnej, w: Praca i odpoczynek $w$ literaturach słowiańskich, red. E. Małek, Wydawnictwo Uniwersytetu Łódzkiego, Łódź, s. 355-362.

Polskije issliedowanija ritoriki i prakticzeskich jejo primienienij, w: Wzaimodiejstwije literatur w mirowom literaturom procesie. Probliemy teoreticzeskoj $i$ istoriczeskoj poetiki, red. A.C. Smirnow, T.E. Awtuchowicz, cz. 1, Grodno, s. 146-155 [wersja polskojęzyczna: Współczesne polskie badania nad retoryka i jej zastosowaniami, „Acta Universitatis Lodziensis. Folia Litteraria Polonica” 2005, t. 7, cz. 1, s. 5-14].

Sztuka czytania w ujęciu wybranych pisarzy, „Acta Universitatis Lodziensis. Folia Litteraria Polonica", t. 6, s. 275-280.

\section{4}

O sztuce komponowania w wymiarze retorycznym i stylistycznym, w: Wielojęzyczność w perspektywie stylistyki i poetyki, red. M. Ruszkowski, Wydawnictwo Akademii Świętokrzyskiej, Kielce, s. 37-52.

Poetyka „prozy internetowej” i „SMS-owej”, „Zeszyty Naukowe Państwowej Wyższej Szkoły Zawodowej we Włocławku. Rozprawy Humanistyczne", t. 2, s. 185-191.

Retoryczność reportaży międzywojnia na wybranych przykładach, w: Reportaż $w$ dwudziestoleciu międzywojennym, red. K. Stępnik, M. Piechota, Wydawnictwo Uniwersytetu Marii Curie-Skłodowskiej, Lublin, s. 53-63.

Stilistika i ritorika zaglavij, w: Imâ teksta, imâ v tekste, red. N.I. Iŝuk-Fadeeva, Liliâ Print, Twer, s. 7-16.

Topos piękna natury. Pogranicza stylistyczno-retoryczne, w: Piękno materialne. Piękno duchowe. Materialy z konferencji, 19-21 maja 2003 r., red. A. Tomecka-Mirek, Archidiecezjalne Wydawnictwo Łódzkie, Łódź, s. 45-54.

Współczesne realizacje stylowo-gatunkowe toposu panegirycznego, „Stylistyka”, t. 13, s. 267-276. 
Wygłaszanie przemówień w ujęciu wspótczesnych retoryk praktycznych, w: Problematyka tekstu głosowo interpretowanego, t. 1, red. K. Lange, W. Sawrycki, P. Tański, Wydawnictwo Adam Marszałek, Toruń, s. 329-336.

\section{5}

Rola retoryki w wychowaniu czytelniczym uczniów, w: Metodyka a nauka o literaturze i nauka o języku, red. D. Michułka, K. Bakuła, Wydawnictwo Wrocławskiego Towarzystwa Naukowego, Wrocław, s. 265-269.

Środki perswazyjne i stylistyka argumentacji w gatunkach publicystycznych, „Forum Artis Rhetoricae", t. 3-4(5-6), s. 6-22.

Topika temporalna $w$ literaturze wspólczesnej, w: Čas v jazyce a v literature. Sborník $z$ mezinárodní konference, red. M. Čechová, D. Moldanová, Z. Millerová, Univerzita J.E. Purkyně, Ústí nad Labem, s. 382-389.

Uwagi o roli tytułu i podtytułu w różnych formach tekstowych, „Zeszyty Naukowe Państwowej Wyższej Szkoły Zawodowej we Włocławku. Rozprawy Humanistyczne", t. 5, s. 21-28.

Współczesne polskie badania nad retoryką i jej zastosowaniami, „Acta Universitatis Lodzensis. Folia Litteraria Polonica", z. 7, t. 1, s. 5-14.

Z problematyki czasu w literaturze wspótczesnej (toposy - motywy - gatunki), „Zeszyty Naukowe Państwowej Wyższej Szkoły Zawodowej we Włocławku. Rozprawy Humanistyczne", t. 4, s. 87-97.

\section{6}

Konteksty stylistyczne i retoryczne, Wydawnictwo „Piktor”, Łódź.

Między literatura i publicystyką, Wydawnictwo „Piktor”, Łódź.

Mirostawa Korolki syntezy i refleksje retoryczne, „Forum Artis Rhetoricae”, nr 1, s. 107-110.

Perspektywy badań nad retoryka dziennikarska, w: Retoryka w Polsce. Teoria i praktyka w ostatnim pólwieczu, red. M. Skwara, Wydawnictwo Naukowe Uniwersytetu Szczecińskiego, Szczecin, s. 169-178.

Wizja czasów minionych w prozie wspomnieniowej Joanny Kulmowej, „Acta Universitatis Lodzensis. Folia Litteraria Polonica", t. 8, s. 391-398.

\section{7}

Ewolucja polskiej terminologii retorycznej w XIX i XX wieku, w: Perspektywy polskiej retoryki, red. B. Sobczak, H. Zgółkowa, Wydawnictwo Poznańskie, Poznań, s. 36-41.

Jak interpretować "literaturę z literatury”?, w: Czytanie tekstów kultury, red. B. Myrdzik, I. Morawska, Wydawnictwo Uniwersytetu Marii Curie-Skłodowskiej, Lublin, s. 125-134. 
Współczesna literatura drogi, czyli podróże w przestrzeni, w: Prostor v jazyce a v literature, red. J. Koten, P. Miller, Univerzita J.E. Purkyně, Usti nad Labem, s. 322-326. Wspótczesna topika imienna, czyli od tradycji do nowatorstwa, w: Co všechno slovo znamená. Sborník př́spěvků věnovaných profesorce PhDr. Marii Čechové, drSc., red. D. Moldanova, M. Balowski, Univerzita J.E. Purkyně, Usti nad Labem, s. 57-64; przedruk w: Tradycja a nowoczesnośc. Materiały z konferencji 14-16 maja 2007 r., red. E. Woźniak, Archidiecezjalne Wydawnictwo Łódzkie, Łódź 2008, s. 479-488.

Zamietki o roli zagławija i podzagołowka $w$ tekstach raznych literaturnych żanrow, w: Imia teksta. Imia w tekstie, red. O. Główko, N. Iszczuk-Fadiejewa, Wydawnictwo Uniwersytetu Łódzkiego, Łódź, s. 17-26.

\section{8}

Dydaktyzm reportaży socrealizmu, „Acta Universitatis Lodziensis. Folia Litteraria Polonica", t. 10, s. 297-304.

Podróże w przestrzeni i w czasie we współczesnej literaturze polskiej, w: Polonistyczne drogi. Księga jubileuszowa poświęcona profesorowi Władysławowi Sawryckiemu $w$ 70. rocznicę urodzin, red. M. Wróblewski, Wydawnictwo Naukowe Uniwersytetu Mikołaja Kopernika, Toruń, s 131-144.

Retoryczność reportaży historycznych, „Forum Artis Rhetoricae”, nr 3-4, s. 161-168. Retoryka pism codziennych na przykładzie "Gazety Wyborczej” i „Rzeczpospolitej”, w: Wypowiedź dziennikarska. Teoria i praktyka. Skrypt dla studentów dziennikarstwa, red. B. Bogołębska, A. Kudra, Wydawnictwo Uniwersytetu Łódzkiego, Łódź, s. 39-54.

Wzajemne relacje przekazów medialnych i literatury (na przykładzie prasy opinii), w: Media studies. Refleksja nad stanem obecnym, red. K. Stepnik, M. Rajewski, Wydawnictwo Uniwersytetu Marii Curie-Skłodowskiej, Lublin, s. 249-256.

\section{9}

„Mój Inny” we współczesnej prozie niefikcjonalnej, w: Ty, já a oni v jazyce a v literaturę. Sborník z mezinárodni konference pořádané Katedrou Bohemistiky PF UJEP $v$ Ústí nad Labem ve dnech 2.-4. záři 2008, red. P. Mitter, K. Toškovát, 2: Část literárněvědná, Univerzita J.E. Purkyně, Usti nad Labem, s. 15-21.

Poczta literacka, czyli porady pisarskie udzielane twórcom nieprofesjonalnym, w: Język żyje. Rzecz o wspótczesnej polszczyźnie, red. K. Ożóg, Wydawnictwo Uniwersytetu Rzeszowskiego, Rzeszów, s. 193-199.

Publicystyka Teresy Torańskiej, „Zeszyty Naukowe Państwowej Wyższej Szkoły Zawodowej we Włocławku. Rozprawy Humanistyczne”, t. 11, s. 495-502.

Retoryka werbalno-wizualna $w$ wybranych gatunkach dziennikarskich $i$ okołodziennikarskich, w: Komunikacja wizualna w przestrzeni społecznej, red. A. Obrębska, Wydawnictwo Primum Verbum, Łódź, s. 77-90. 
Spotkania z innościa literacka i kulturowa w dydaktyce polonistycznej, w: Edukacja polonistyczna w obliczu przemian kulturowych Europy dawniej i dziś, red. E.B. Kruszyńska, W. Sawrycki, M.A. Wróblewski, Wydawnictwo Naukowe Uniwersytetu Mikołaja Kopernika, Toruń, s. 9-20.

Style Ryszarda Kapuścińskiego, w: Język i styl twórcy w kręgu badań współczesnej humanistyki. Studia o języku i stylu artystycznym, t. 5, red. K. Maćkowiak, C. Piątkowski, J. Gorzelana, Oficyna Wydawnicza Uniwersytetu Zielonogórskiego, Zielona Góra, s. 33-40.

Tuwimowskie inspiracje intelektualno-twórczych zabaw uczniowskich, w: Dziecko w świecie zabawy. O kulturze, cechach i wartościach ludycznej edukacji, red. B. Dymara, Oficyna Wydawnicza „Impuls”, Kraków, s. 125-132.

\section{0}

Fideistyczna retoryka w wybranych utworach polskiej poezji wspótczesnej, w: Miscellanea literackie i teatralne (od Kochanowskiego do Mrożka). Profesorowi Janowi Okoniowi przez przyjaciót i uczniów na 70. urodziny zebrane, cz. 2, red. K. Płachcińska, M. Kuran, Wydawnictwo Uniwersytetu Łódzkiego, Łódź, s. 143-152.

O niektórych przejawach kultury postmodernistycznej $w$ dziennikarstwie na przykładzie gatunków prasowych, w: Styl - dyskurs - media, red. B. Bogołębska, M. Worsowicz, Wydawnictwo Uniwersytetu Łódzkiego, Łódź, s. 115-122.

Pisarskie idiolekty felietonistów (Joanna Szczepkowska, Daniel Passent, Olga Lipińska), w: Horyzonty polonistyki. W kręu edukacji, języka i kultury, red. M.E. Karwatowska, M. Latoch-Zielińska, I.E. Morawska, Wydawnictwo Uniwersytetu Marii Curie-Skłodowskiej, s. 197-206.

Poetyka liberatury, czyli o wielości wersji tekstu i generowaniu nowych sensów, w: Ilość - wielkość - wartość. Materialy z konferencji 11-13 maja 2009, red. E. Umińska-Tytoń, Archidiecezjalne Wydawnictwo Łódzkie, Łódź, s. 17-24.

Prasa szkolna międzywojnia a ksztaltowanie postaw twórczych uczniów, „Edukacja Humanistyczna" [Zielona Góra], t. 6-7, s. 137-142.

Retoryczne sposoby oddziaływania na czytelnika $w$ tekście prasowym, w: O mediach $i$ komunikacji. Skrypt dla studentów dziennikarstwa i komunikacji społecznej, red. E. Pleszkun-Olejniczakowa, J. Bachura, M. Worsowicz, Wydawnictwo Uniwersytetu Łódzkiego, Łódź, s. 105-114.

Stylistyka utworów prozatorskich i dramatycznych o Janie Pawle II, w: Karol Wojtyła - Jan Pawet II. Stowa prawdy i życia. Szkice lingwistyczne, red. K. Ożóg, B. Taras, Wydawnictwo Uniwersytetu Rzeszowskiego, Rzeszów, s. 78-86.

\section{1}

Anna Świderkówna - popularyzatorka Biblii, w: Autorytety w perspektywie chrześcijańskiej, red. B. Bogołębska, M. Worsowicz, Wydawnictwo Uniwersytetu Łódzkiego, Łódź, s. 89-96. 
Fotograficzna technika utrwalania rzeczywistości w cyklu opowiadań Janusza Andermana, w: Svět kreslený slovem, red. M. Balowski, M. Hádková, Filozofická fakulta Univerzity Jana Evangelisty Purkyně v Ústí nad Labem, Ústí nad Labem, s. 89-96.

Kształcenie retoryczne dziennikarzy w Uniwersytecie Łódzkim, w: Dydaktyka retoryki, red. B. Sobczak, H. Zgółkowa, Wydawnictwo Poznańskie, Poznań, s. 86-89.

Literackie żywoty świętych - mimetyzm i gry z konwencją gatunkowa, w: „Największa jest miłość" (1 Kor 13,13). Książka dedykowana Metropolicie łódzkiemu abp. Władysławowi Ziólkowi protektorowi Instytutu Teologicznego w Łodzi z racji rocznicy posługiwania $w$ archidiecezji, seria: „Żyć ewangelią w III tysiącleciu”, t. 3, red. S. Skobel, Instytut Teologiczny, Łódź, s. 135-144.

Pasaże i przypowieści Krzysztofa Rutkowskiego z retorycznego punktu widzenia, $\mathrm{w}$ : Rhetorica regina artis scientiaeque, red. S. Górzyński, Wydawnictwo DiG, Warszawa, s. 59-66.

Przekraczanie granic publicystyki i literatury (na wybranych przykładach), w: Mistrzowie literatury czy dziennikarstwa?, red. K. Wolny-Zmorzyński, W. Furman, J. Snopek, Wydawnictwo Poltext, Warszawa, s. 17-24.

Relacje między tworzeniem a odtwarzaniem $w$ gatunkach prasowych, w: Dyskursy komunikacji medialnej, red. A. Filipczak-Białkowska, seria: „Poznawać. Tworzyć. Komunikować”, Wydawnictwo Primum Verbum, s. 17-23.

\section{2}

„Karafka La Fontaine'a” Melchiora Wańkowicza odczytana po latach, czyli o sile perswazji, w: Język nowych mediów i nowej literatury, red. K. Michalewski, Wydawnictwo Primum Verbum, Łódź, s. 13-20.

Listy z podróży - odmiany gatunkowo-komunikacyjne, „Liubosłowije. Godiszno Spisanije za Humanitaristika”, nr 12, s. 88-94.

Perswazyjność prasowych gatunków wypowiedzi polityków, „Forum Artis Rhetoricae", nr 2, s. 45-54.

Stylistyka interakcyjna tekstów dziennikarskich, w: Język w mediach. Antologia, red. M. Kita, I. Loewe, Wydawnictwo Uniwersytetu Śląskiego, Katowice, s. 65-73.

\section{3}

Mistrzowie i uczniowie dziennikarskiego rzemiosła Ryszarda Kapuścińskiego, w: Mistrz i uczeń. Zbiór studiów, red. D. Bieńkowska, J. Lewandowicz, Archidiecezjalne Wydawnictwo Łódzkie, Łódź, s. 5-13.

Od tradycji do nowatorstwa, od transgresji do adaptacji na wybranych przykładach literackich i publicystycznych, Wydawnictwo Primum Verbum, Łódź.

Progymnasmata i afekty $w$ Prusowskiej teorii dzieła literackiego, „Forum Artis Rhetoricae”, t. 4, z. 35, s. 36-43. 
Sowriemiennoje ponimanije poniatija „żurnalistskaja stilistika”, w: Stilistika kak rieczewiedienije, red. L.R. Duskajewa, Izdatiel'stwo Flinta, Moskwa, s. 155-161. Styl i sztuka pisarska wedlug Bolesława Prusa, „Stylistyka”, t. 22, s. 65-74.

Wspótczesne rozumienie pojęcia „stylistyka dziennikarska”, w: Sławianskaja stilistika. Wiek XXI. Sbornik statjej, red. L.R. Duskajewa, Sankt-Peterburgskij Gosudarstwiennyj Uniwiersitiet, Sankt Petersburg, s. 170-177.

\section{4}

Funkcja tekstów w tekście (na przykładzie gatunków dziennikarskich), „Medialingwistika", nr 3: Recziewyje żanry w massmedia, s. 13-17.

Kreatywność dziennikarska - między kulturą subiektywna a obiektywna, „Naukowy Przegląd Dziennikarski”, nr 4, s. 88-100.

Retoryka wojenna w ksiażce Krzysztofa Millera „13 wojen i jedna”, „Forum Artis Rhetoricae", nr 4, z. 39, s. 35-40.

Stilisticzeskije osobiennosti rieportażej Wojciecha Tochmana, „Medialingwistika”, nr 1(4), s. 27-33.

Stylistyka interakcyjnatekstów dziennikarskich, w: Język wmediach. Antologia, red. M. Kita, I. Loewe, wyd. 2, Wydawnictwo Uniwersytetu Śląskiego, Katowice, s. 67-75.

\section{5}

Badania retoryczne w Katedrze Dziennikarstwa i Komunikacji Społecznej oraz w Zakładzie Teorii i Praktyki Komunikacji UŁ, współautor: G. Habrajska, „Forum Artis Rhetoricae", nr 3(42), s. 53-61.

Kreatywność dziennikarska - między kultura subiektywną a obiektywna, w: O wspótczesnym dziennikarstwie: sztuka i polityka, red. K. Wolny-Zmorzyński, K. Kowalik, K. Bernat, M. Zimnoch, Towarzystwo Studiów Dziennikarskich, WarszawaKraków-Rzeszów, s. 88-101.

Lęk jako dominujące uczucie w narracjach literackich i nieliterackich Grażyny i Wojciecha Jagielskich, w: Matieriali III miżnarodnoj naukowo-prakticznoj konfierien$c j i$, „Naukowa szkoła Romana Iwanczenka”, Nacjonalnyj Technicznij Uniwiersitiet Ukraini, Kijów, s. 245-253.

Mariaż gatunków dziennikarskich i użytkowych oraz gry z konwencja gatunkowa, w: Gatunki mowy i ich ewolucja, t. 5: Gatunek a granice, red. D. Ostaszewska, J. Przyklenk, Wydawnictwo Uniwersytetu Śląskiego, Katowice, s. 261-270.

Ot riemiesliennika do chudożnika. Isskusstwo pisatiel'skogo mastierstwa w SMI, „Miedialingwistika”, nr 3(9), s. 55-63.

Prasowe eksperymenty gatunkowe, w: Gatunki i formaty we wspótczesnych mediach, red. nauk. W. Godzic, A. Kozieł, J. Szylko-Kwas, Wydawnictwo Poltext, Warszawa, s. 71-82.

Retoryka, genologia i stylistyka tekstów literackich i dziennikarskich, Wydawnictwo Primum Verbum, Łódź. 
Wartości i uczucia we współczesnych polskich reportażach, „Acta Universitatis Lodziensis. Folia Litteraria Rossica”, nr 8, s. 241-250; przedruk w: „Forum Artis Rhetoricae" 2015, nr 3, s. 21-33.

\section{6}

Inwencyjność publicystyki na wybranych przykładach, w: Komunikatywizm - przyszłość nauki XXI wieku, red. G. Habrajska, Wydawnictwo Primum Verbum, Łódź, s. 235-247.

Lęk jako dominujace uczucie w narracjach literackich i nieliterackich Grażyny i Wojciecha Jagielskich, w: Apetyt na rzeczywistość. Między literatura a dziennikarstwem - relacje, interakcje, perspektywy, red. E. Kobyłecka-Piwońska, A. Kłosińska-Nachin, Wydawnictwo Uniwersytetu Łódzkiego, Łódź, s. 199-209.

Przenikanie się dyskursów dziennikarskich i medialnych, w: Dyskurs i jego odmiany, red. B. Witosz, K. Sujkowska-Sobisz, E. Ficek, Wydawnictwo Uniwersytetu Śląskiego, Katowice, s. 244-253.

Retoryczna kategoria „uwodzenia” na przykładzie literackich zabaw językowo-gatunkowych, w: Retoryka tekstu artystycznego. Gry semantyczne, red. A. Majmieskułow, Wydawnictwo Uniwersytetu Kazimierza Wielkiego, Bydgoszcz, s. 95-104.

Retoryczne zabiegi $w$ tematycznych odmianach dziennikarstwa prasowego, „Acta Universitatis Lodziensis. Folia Litteraria Polonica", nr 1(31), s. 49-58.

Retoryka i jej zastosowania. Podręcznik dla studentów dziennikarstwa i innych kierunków humanistycznych, współautor: M. Worsowicz, Wydawnictwo Uniwersytetu Łódzkiego, Łódź.

Stylistyka różnych odmian dziennikarstwa na przykładzie prasy, w: Język a media. Zjawiska językowe we współczesnych mediach, red. B. Skowronek, E. Horyń, A. Walecka-Rynduch, Collegium Columbinum, Kraków s. 55-64.

Teksty publicystyczne jako przykłady „palimpsestów”, w: Matieriali IV miżnarodnoj naukowo-prakticznoj konfieriencji, „Naukowa szkoła Romana Iwanczenka”, Nacjonalnyj Technicznij Uniwiersitiet Ukraini, Kijów, s. 151-160.

Tischnerowskie „formy pamięci”, „Łódzkie Studia Teologiczne”, nr 1(25), s. 29-40.

\section{7}

Obecność progymnasmatów i form spekulatywno-argumentacyjnych $w$ tekstach literackich i filozoficznych Leszka Kołakowskiego, „Forum Artis Rhetoricae”, nr 1, s. 9-17.

Przydatność instrumentarium retorycznego i metod retorycznej analizy tekstu $w$ badaniach nad gatunkami medialnymi, w: Wspótczesne media. Gatunki w mediach. Prace dedykowane Profesor Marii Wojtak, t. 1: Zagadnienia teoretyczne. Gatunki w mediach drukowanych, red. I. Hofman, D. Kępa-Figura, Wydawnictwo Uniwersytetu Marii Curie-Skłodowskiej, Lublin, s. 53-64. 
Retoryczna genealogia sztuki komponowania tekstów - jej aktualizacje i modyfikacje, w: Retoryka klasyczna i retoryka współczesna. Pola i perspektywy badań, red. C. Mielczarski, Wydawnictwo Naukowe „Sub Lupa”, Instytut Filologii Klasycznej Uniwersytetu Warszawskiego, Warszawa, s. 119-128.

Zastosowanie retorycznych progymnasmatów we wspólczesnym komunikowaniu, w: Powinowactwa retoryki, red. B. Sobczak, Wydawnictwo Naukowe Uniwersytetu Adama Mickiewicza, Poznań, s. 57-66.

\section{8}

Aksjologiczny wymiar retoryki krytycznej i afirmatywnej w gatunkach prasowych, „Obri Drukarstwa”, [Nacjonalnyj Technicznij Uniwiersitiet Ukraini], nr 1, s. 352-361.

Negacja i antytetyczność jako zjawiska retoryczne (na wybranych przykładach), w: Negacja w języku, tekście, dyskursie, red. E. Szkudlarek-Śmiechowicz, B. Cieśla, Wydawnictwo Uniwersytetu Łódzkiego, Łódź, s. 41-50.

Parafrazowanie jako ćwiczenie stylistyczne i przykład formy pisarskiej. Genealogia i współczesność, w: Parafrazowanie w dyskursie artystycznym, red. G. Habrajska, Wydawnictwo Primum Verbum, Łódź, s. 72-81.

Religijność we współczesnych reportażach, „Łódzkie Studia Teologiczne”, z. 1(27), s. 37-47.

Retoryczność i publicystyczność tekstów Wojciecha Młynarskiego, w: „Strasznie lubie cię, piosenko". Szkice o tekstach Wojciecha Mlynarskiego. Tom jubileuszowy dedykowany Profesor Barbarze Kudrze, red. K. Burska, E. Olejniczak, Wydawnictwo Uniwersytetu Łódzkiego, Łódź, s. 163-168.

Wspótczesne gatunki i style wobec tradycji retorycznej, Wydawnictwo Primum Verbum, Łódź.

\section{Część II - prace redagowane, recenzje, hasła słownikowe, biogramy, głosy w dyskusji, inne}

Redakcja numerów czasopisma naukowego „Acta Universitatis Lodziensis. Folia Litteraria Polonica": 2007, t. 9; 2008, t. 10, 11;2009, t. 12; 2010, t. 13;2011, t. 14; 2012, t. 17; 2013, t. 19, 20, 21, 22.

\section{8}

[rec. książki: Metodika prepodavanija literatury, izd. 2, Moskva 1985], „Dydaktyka Literatury", t. 9, s. 207-213.

\section{1}

[rec. książki: Mirosław Korolko, Sztuka retoryki. Przewodnik encyklopedyczny, Warszawa 1990], „Ruch Literacki”, R. 32, z. 4, s. 429-430. 
[rec. książki: Teresa Zaniewska, Retoryka szkolna. Polskie tradycje i doświadczenia dziewiętnastowieczne, Białystok 1991], „Ruch Literacki”, R. 22, z. 6(195), s. 740-742.

\section{3}

Stefania Skwarczyńska. 1902-1988, w: Sprawozdania z czynności i posiedzeń. 1982-1991, zebrał i oprac. H. Klimkiewicz, Łódzkie Towarzystwo Naukowe, Łódź, s. 224-228.

\section{4}

Bańkowski Piotr (1885-1976), [biogram], w: Słownik badaczy literatury polskiej, red. J. Starnawski, Wydawnictwo Uniwersytetu Łódzkiego, Łódź, s. 22-26.

Budrecka Aleksandra Ludwika z d. Palusińska (1939-1981), [biogram], w: Słownik badaczy literatury polskiej, red. J. Starnawski, Wydawnictwo Uniwersytetu Łódzkiego, Łódź, s. 46-48.

Butkiewiczówna-Różycka Irena (1908-1973), [biogram], w: Słownik badaczy literatury polskiej, red. J. Starnawski, Wydawnictwo Uniwersytetu Łódzkiego, Łódź, s. 48-49.

Czapczyński Tadeusz (1884-1958), [biogram], w: Słownik badaczy literatury polskiej, red. J. Starnawski, Wydawnictwo Uniwersytetu Łódzkiego, Łódź, s. 55-61.

[rec. książki: Stanisław Dubisz, Język i polityka. Szkice z historii stylu retorycznego, Warszawa 1992], „Stylistyka”, t. 3, s. 238-241.

Dyskutować..., ale jak?, „Biuletyn Seminaryjny”, R. 2 nr 4(5), s. 4.

Hajkowski Zygmunt (1889-1942), [biogram], w: Słownik badaczy literatury polskiej, red. J. Starnawski, Wydawnictwo Uniwersytetu Łódzkiego, Łódź, s. 112-115.

Hrabec Stefan (1912-1972), [biogram], w: Słownik badaczy literatury polskiej, red. J. Starnawski, Wydawnictwo Uniwersytetu Łódzkiego, Łódź, s. 115-118.

Kaczmarek Włodzimierz Stanisław (1930-1962), [biogram], w: Słownik badaczy literatury polskiej, red. J. Starnawski, Wydawnictwo Uniwersytetu Łódzkiego, Łódź, s. 121-122.

Klepacz Michat (1893-1967), [biogram], w: Słownik badaczy literatury polskiej, red. J. Starnawski, Wydawnictwo Uniwersytetu Łódzkiego, Łódź, s. 128-130.

Kunowski Stefan (1909-1977), [biogram], w: Słownik badaczy literatury polskiej, red. J. Starnawski, Wydawnictwo Uniwersytetu Łódzkiego, Łódź, s. 165-167.

[rec. książki: Władysław Sawrycki, Wiedza o literaturze w szkolnej refleksji polonistycznej w latach 1869-1939, Toruń 1993], „Ruch Literacki”, z. 5-6, s. 598-599.

Weychert-Szymanowska Władysława (1874-1951), [biogram], w: Słownik badaczy literatury polskiej, red. J. Starnawski, Wydawnictwo Uniwersytetu Łódzkiego, Łódź, s. 314-316.

Woroniecki Jacek Adam (1878-1949), [biogram], w: Słownik badaczy literatury polskiej, red. J. Starnawski, Wydawnictwo Uniwersytetu Łódzkiego, Łódź, s. 331-334.

Wróblewska Elżbieta Maria (1938-1980), [biogram], w: Słownik badaczy literatury polskiej, red. J. Starnawski, Wydawnictwo Uniwersytetu Łódzkiego, Łódź, s. 334-336. 


\section{5}

Bolesław Felicjan Kielski (1879-1965), pedagog, romanista, komparatysta wkraczajacy w literaturę polska, wydawca, działacz społeczny, kulturalny i oświatowy, ttumacz, w: Sprawozdania z Czynności i Posiedzeń Naukowych, t. 49, Łódzkie Towarzystwo Naukowe, Łódź, s. 139-145.

\section{6}

Orientacje stylistyczne, [omówienie zawartości: „Stylistyka”, t. 1-5], „Poradnik Językowy", z. 2, s. 62-64.

[rec. książki: Zbigniew Kloch, Spory o język, Warszawa 1995], „Poradnik Językowy”, z. 2, s. 55-57.

\section{8}

[rec. książki: Czesław Jaroszyński, Piotr Jaroszyński, Podstawy retoryki klasycznej, Warszawa 1998], „Ruch Literacki”, z. 6, s. 835-837.

[rec. książki: Zofia Mitosek, Mimesis. Zjawisko i problem, Warszawa 1997], „Stylistyka", t. 7, s. 443-447.

\section{9}

Inspiracje chrześcijańskie w kulturze Europy, [sprawozdanie], „Warsztaty Polonistyczne", nr 3, s. 102-104.

\section{0}

Doleżan Wiktor Kazimierz (1870-1917), [biogram], w: Stownik badaczy literatury polskiej, red. J. Starnawski, t. 3, Wydawnictwo Uniwersytetu Łódzkiego, Łódź, s. 91-92.

Furmanik Stanisław (1896-1972), [biogram], w: Słownik badaczy literatury polskiej, red. J. Starnawski, t. 3, Wydawnictwo Uniwersytetu Łódzkiego, Łódź, s. 101-104. Jarecki Kazimierz Wiktor (1878-1939), [biogram], w: Słownik badaczy literatury polskiej, red. J. Starnawski, t. 3, Wydawnictwo Uniwersytetu Łódzkiego, Łódź, s. $158-160$.

Lipski Jan Józef (1926-1991), [biogram], w: Słownik badaczy literatury polskiej, red. J. Starnawski, t. 3, Wydawnictwo Uniwersytetu Łódzkiego, Łódź, s. 240-246.

Niemojewska-Gruszczyńska Zofia (1891-1960), [biogram], w: Słownik badaczy literatury polskiej, red. J. Starnawski, t. 3, Wydawnictwo Uniwersytetu Łódzkiego, Łódź, s. 285-287.

Nitowski Jan (1859-1926), [biogram], w: Stownik badaczy literatury polskiej, red. J. Starnawski, t. 3, Wydawnictwo Uniwersytetu Łódzkiego, Łódź, s. 287-288.

Rogalski Aleksander (1912-1996), [biogram], w: Słownik badaczy literatury polskiej, red. J. Starnawski, t. 3, Wydawnictwo Uniwersytetu Łódzkiego, Łódź, s. 314-318. 
Skulski-Mastycz Ryszard (1890-1951), [biogram], w: Słownik badaczy literatury polskiej, red. J. Starnawski, t. 3, Wydawnictwo Uniwersytetu Łódzkiego, Łódź, s. 339-342.

Smosarski Józef (1935-1997), [biogram], w: Słownik badaczy literatury polskiej, red. J. Starnawski, t. 3, Wydawnictwo Uniwersytetu Łódzkiego, Łódź, s. 347-348.

Suchodolski Bogdan (1903-1992), [biogram], w: Słownik badaczy literatury polskiej, red. J. Starnawski, t. 3, Wydawnictwo Uniwersytetu Łódzkiego, Łódź, s. 364-368.

Syga Teofil Bernard (1903-1983), [biogram], w: Słownik badaczy literatury polskiej, red. J. Starnawski, t. 3, Wydawnictwo Uniwersytetu Łódzkiego, Łódź, s. 369-370.

Warszawski Józef SJ (1903-1997), [biogram], w: Słownik badaczy literatury polskiej, red. J. Starnawski, t. 3, Wydawnictwo Uniwersytetu Łódzkiego, Łódź, s. 389-391.

\section{1}

Barowa-Święchowa Irena Zofia z Turowskich, [biogram], w: Stownik badaczy literatury polskiej, red. J. Starnawski, t. 4, Wydawnictwo Uniwersytetu Łódzkiego, Łódź, s. 13-14.

[rec. książki: Marie Čechová, Komunikačni a slohová vychová, Praha 1998], „Poradnik Językowy", z. 5, s. 63-65.

[rec. książki: Mirosław Korolko, Leksykon kultury religijnej w Polsce, Warszawa, 1999], „Przegląd Powszechny”, nr 5, s. 247-248.

\section{3}

[rec. książki: Libor Pavera, František V̌̌etička, Lexikon literárních pojmů, Olomouc 2002], „Bohemistyka”, nr 2, s. 163-164.

\section{6}

[rec. książki: Raymond Queneau, Ćwiczenia stylistyczne, Izabelin 2005], „Stylistyka”, t. 15 , s. $454-461$.

\section{7}

[rec. książki: Tamara A. Awtuchowicz, Poezija ritoriki..., Mińsk 2005] „Forum Artis Rhetoricae", t. 1(7), s. 99-100.

\section{8}

[rec. książki: Latino-jazycznyje ritoriki na Biełarusi: połockij traktat „O ritorczeskom iskustwie...” 1788, 1799, red. I.B. Krawczuk, Mińsk 2006], „Forum Artis Rhetoricae", t. 12-13, s. 93-94. 
2010

Pasaż, „Zagadnienia Rodzajów Literackich”, R. 53, z. 1-2(105-106), s. 264-265.

Poczta literacka, „Zagadnienia Rodzajów Literackich”, R. 53, z. 1-2(105-106), s. 265. Styl - dyskurs - media, współred. M. Worsowicz, Wydawnictwo Uniwersytetu Łódzkiego, Łódź.

\section{1}

Autorytety w perspektywie chrześcijańskiej, współred. M. Worsowicz, Wydawnictwo Uniwersytetu Łódzkiego, Łódź.

[rec. książki: Mirosław Korolko, Podręcznik retoryki homiletycznej, Kraków 2010], „Forum Artis Rhetoricae”, t. 2(25), s. 155-157.

\section{2}

Łódzkie media dawniej i dziś, współred. J. Mikosz, Wydawnictwo Uniwersytetu Łódzkiego, Łódź.

\section{3}

Dialog wiary z nauką i kultura, współred. M. Worsowicz, Wydawnictwo Uniwersytetu Łódzkiego, Łódź.

Wypowiedź dziennikarska. Teoria i praktyka. Skrypt dla studentów dziennikarstwa, współred. A. Kudra, Wydawnictwo Uniwersytetu Łódzkiego, Łódź.

\section{5}

Wychowanie dzieci po stracie męża, „Społeczeństwo”, nr 3-4, s. 120-121.

\section{6}

Chrześcijańska myśl, kultura i edukacja, współred. M. Worsowicz, Wydawnictwo Uniwersytetu Łódzkiego, Łódź.

\section{8}

Poszukiwania teologiczno-filozoficzno-kulturowe, współred. M. Worsowicz, Wydawnictwo Uniwersytetu Łódzkiego, Łódź. 